\title{
Request Strategies in Indonesian: An Analysis of Politeness Phenomena in Text Messages
}

\author{
Jeanyfer \& Trisnowati Tanto \\ jeanyfer.tanusy@gmail.com \& trisnowatitanto@gmail.com \\ English Department, Universitas Kristen Maranatha Bandung
}

\begin{abstract}
A lot of linguists have paid a lot of attention to the phenomena of politeness-some said it should be in the area of Sociolinguistics, while others believe that it belongs to the domain of Pragmatics. The present study focuses on politeness phenomena as a part of Pragmatic domain as it aims to see how language, especially Indonesian, is used to realize politeness in text messages between people who would like to request a favor, thing, or information. It is believed that speakers use different strategies to achieve their goals when talking to different people. The study utilizes Brown's and Levinson's theory on politeness strategies to examine the strategies used by the speaker when communicating with hearer of different power and distance relations. Along with the theory, this study also employs request strategies that are derived from Searle's speech act classifications. The result shows that in terms of strategies, people have the tendency to use negative politeness strategies in communicating with other people that have more power than them, while a mix between negative and positive strategies are used mostly to those they consider peer or lower in power.
\end{abstract}

Keywords: politeness strategies, request strategies, speech acts, pragmatics

\section{Introduction}

The notion of 'politeness' has become a particular interest among linguists in the past three decades despite its controversy on whether it belongs to the domain of Pragmatic or merely a Sociolinguistic phenomenon. Yule (1996) describes politeness as a fixed concept in the form of 'polite social behavior' in a particular culture, a concept that is agreed upon by Leech (2014) who believes that to be polite to others means to speak in a way that gives benefit to the person we are conversing with. Some linguists-amongst them Lakoff, Fraser and Leech-base their theories of Politeness strategies on Grice's cooperative principles, saying that they are the cornerstone for politeness as the more one seeks to communicate a message directly to achieve full clarity, the more one moves away from an expression of politeness (El-Samir, 2016).

Meanwhile, Brown and Levinson take a more sociological approach to the strategies by adopting the notion of Goffman's theory of interpersonal communication: 'Face.' This theory has been a subject of criticism as it is said not to accommodate the cultures and languages in Asia (Yule, 2006).

Even though speech acts are considered to be a universal pragmatic operation (Leech, 1983), the uses differ across languages and cultures. As Shariati and Chamani (2010) put it, it is important to see how language is realized in different languages in order to establish universal features of speech acts. In other words, as pragmatic use of language is 
universal, one should base this on empirical data taken from different languages.

This study examines text-messages taken from the messaging applications WhatsApp and Line Messenger focusing on the language of the speakers when requesting favors, things, and/or information to hearers of different power and distance relations from the speakers. Using Brown and Levinson's politeness strategies as well as Austin's and Searle's speech acts theories and classifications, the study aims to see the degree of indirectness through politeness strategies in regards of power, distance and degree of imposition between speakers.

\section{Literature Reviews Speech Act Theory}

Speech act theory was first founded by Austin in 1962, basing on his belief that the use of language always serves different communicative functions to accomplish certain purposes. These utterances-called speech acts-are divided into three different layers (Yule, 1996): locutionary act, in which an utterance is a meaningful linguistic expression; illocutionary act, which bears a communicative force to achieve a particular purpose; and perlocutionary act, which is the effect of the utterance to the hearer. From all three, Austin considers that the illocutionary act is the most important as it bears the meaning of what the speaker actually wants to achieve by uttering an utterance.

The importance of illocutionary act is also recognized by Searle, who further divides it into five sub-categories of declarations (e.g. resign, appoint, fire somebody, etc.), representatives (e.g. suggesting, denying, etc.), expressives (e.g. congratulate, apologize, etc.), directives (e.g. order, request, invite, etc.), and commissives (e.g. promise, vow, etc.) (Yule, 1996).

Searle proposes that all speech acts are indirect to some degree, and it is a matter of understanding the indirectness of an utterance that becomes a problem. As an example, Al-Marrani (2010) states that a question such as "can you reach the dictionary?" is not merely a yes-or-no question but poses as an indirect request. For the purpose of this study, speech act theory will provide insights on people's requesting behavior in text messages to different hearers with different power and distance relations from themselves.

\section{The Speech Act of Request}

In accordance to Searle's classifications of illocutionary acts, 'request' falls into the category of directives, which is regarded as "the speech acts that speakers use to get someone else to do something" (Yule, 1996). This may be conducted directly or indirectly-or, in Reiter's (2000) words, respectively, head act and peripheral modification devices. A head act consists of the main utterance which has the function of requesting and can stand on its own, for instance "can you lend me some money?" On the other hand, peripheral modification devices are optional and serve to mitigate or intensify the force of the requesting move (Silfianou, 1999) and are made up of two main groups: internal modifiers-devices that appear within the same request head act (e.g. do you think you can lend me some money?) - and external modifiers, the modifiers appearing in the immediate linguistic context surrounding the request head act, either preceding or following it (e.g. Can you lend me some money? I forgot my wallet).

Some previous research conducted on the use of this particular speech act has focused on either the request head act itself (Aribi, n.d.; Yang, 2009) or only the modification devices (Sattar and Farnia, 2014), but there are also researches focusing on both the request head act and the modification devices, like the one conducted by Beltran and Flor (n.d.). Following Beltran and Flor, the present study focuses on both functions as it is believed to convey more about the relationship between indirectness and the power, distance and degree of imposition among speakers.

\section{The Concept of 'Face'}

The concept of 'face' is defined by Yule (1996) as the public self-image of a person, 
referring to the emotional and social sense of self that everyone has and expects others to recognize. People should be considerate of others' face in order to maintain interpersonal relationship and ensure successful social interaction. Brown and Levinson (cited in Black, 2006) describe the two aspects of face as negative face and positive face-the former being the right to be independent and not to be imposed by other people while the latter being the need to be accepted and to be treated as a member of the same group. Based on this concept, the speech act of requests, being a directive, is considered a Face Threatening Act (FTA) since in the act a speaker imposes their will on the hearers, and therefore (possibly) threatens the face of the hearers. I believe that this concept also helps me to see the connection between the (in)directness of a request with power and distance relations.

\section{Brown's and Levinson's Politeness Strategies}

Every society has their own culture and norms regarding how people should interact with one another. Brown and Levinson offer a descriptive analysis of strategies used by the participants to maintain their respective faces in social interaction, which can be summed up into five strategies: 1) bald on-record, 2) positive politeness, 3) negative politeness, 4) off-record, and 5) no Face Threatening Act (FTA). Save for the last one, all strategies are further divided into smaller sub-strategies (Grundy, 2008). Grundy (2008) mentions that in analyzing politeness phenomena, one should always consider the following equation: Social Distance (D) + Power Differential $(\mathrm{P})+$ Ratio of Imposition $(\mathrm{R})=$ degree of face-threat to be redressed by appropriate linguistic strategies. Thus, this concept will help the researcher in drawing hypothesis for the purpose of this study.

As are previous researches, the present study also attempts to identify the strategies used by speakers to reveal how power and distance relate to the strategies used by a speaker. Since the data are in the form of written texts, the strategies observed are only the first four mentioned above and the sub- strategies within the four. Strategy five, no FTA, is not relevant to this research and therefore is not observed.

\section{Methodology}

This study uses a descriptive qualitative approach, which is defined by Bodgan and Biklen (1982) to bring about the descriptive data in the written and oral form from the subjects being investigated. Since a qualitative research focuses on words instead of numbers or measures, the data and analysis in this study is conducted in descriptive forms, after which a conclusion is drawn without making generalization.

\section{Data Collection}

This study is based on the text messages in the messaging applications WhatsApp and Line Messenger, both private and group conversations. The data were obtained through two different methods: 1) through text messages that come naturally between the researcher and other people, and 2) through participants who sent the screenshots of their text messages to the researcher. The second method was employed due to the time constraint for the data collection which did not allow all data to be collected naturally.

In terms of ethical issues that may arise due to the nature of the data, the participants have been made aware that their personal messages will be used for the purpose of this present study and they have also given their personal consent.

\section{Data Analysis}

After the data were collected and selected, they were analyzed using the speech act of request framework and assigned into different strategies based on Brown's and Levinson's theory. The analysis consists of the process of classifying the data into its categories so that a working hypothesis may be formulated from the findings.

In analyzing the data, the researchers did several steps beginning with classification 
of power and distance relations between the speakers. The next step was assigning the strategies used by speakers in requesting a favor, thing, or information while paying attention to the language use of each request-whether they mostly use head acts or employing modification devices in connection to the intended hearers. Afterward, the researchers interpreted and described the data to answer the research problem before presenting the conclusion.

\section{Results and Discussion}

Relating to social power between speakers and hearers, request strategies can be classified into three categories as follows: higher-ranking to lower-ranking, equal to equal, and lower-ranking to higher-ranking (Blum-Kulka in Aribi, n.d.). Another variable that plays a role in this is the social distance between the speaker and the hearer; the ranking of imposition-either high or low-is also considered. The following table shows the summary of the number of collected data classified according to their social power and distance.

Table 1 Number of data classified according to social power and distance

\begin{tabular}{|c|c|c|}
\hline Power Relation & Social Distance & Number of Data Collected \\
\hline +P & +D & 11 \\
\hline +P & -D & 12 \\
\hline -P & +D & 3 \\
\hline -P & $-D$ & 11 \\
\hline -P & +D & 8 \\
\hline -P & -D & 5 \\
\hline & Total & $\mathbf{5 0}$ \\
\hline
\end{tabular}

Twenty-three out of fifty data collected by the researcher belong to the category of lowerranking speaker talking to higher ranking speaker, while only thirteen are in the category of higher-ranking speaker to lowerranking one and fourteen are of equal power relations. Each of the data presents different strategies which will be discussed further below.

\section{Request Strategies Used by Lower- Ranking Speaker to Higher-Ranking Hearer}

In regards to power relation, speaker who considers him/herself powerless compared to the hearer tends to employ several strategies, which are also determined by the distance between them in addition to the ranking of imposition (what is required of the hearer).

The findings show that when a speaker puts him/herself in a lower position compared to and do not have close social distance with the hearer, he/she tends to employ negative politeness strategy. Moreover, speakers of lower-ranking power status opt to use modification devices, both internal and external, in their speech act in order to mitigate the ranking of imposition and to lessen the threatening of the hearer's face. Below is an example:

\section{Datum 1}

JT: Selamat sore, Pak. Maaf mengganggu lagi. Saya diminta tolong [name] untuk menanyakan kpd Bapak ttg kemungkinan rapat terbatas di hari Senin siang apabila jdwl Bapak memungkinkan. Tp kalau Bapak sibuk maka kami akan menyesuaikan lagi. Hatur nuhun.

The above example is a conversation between a student and her lecturer, talking about the possibility of making an appointment for a meeting. The datum shows that the speaker uses several negative politeness strategies. By using the address term 'Pak', which means 'Mister' and is commonly used in Indonesian to refer to an older (and more respected) male, the speaker shows deference, effectively putting the hearer in the position of power. The phrase 'maaf mengganggu' and the word 'lagi', or in English 'sorry to bother' and 'again' are two other examples of the use of negative politeness strategy-apologizing and hedging. In this case, the speaker again expresses deference and wants be seen as less imposing to the hearer. The sentences following it are a 
combination of several strategies, namely being indirect, minimizing imposition, and hedging. The use of the plural 'kami'-'we'instead of the singular 'saya', the Indonesian formal word to refer to oneself, shows that the speaker tries to impersonalize themselves in order that the hearer's face is not threatened. In lessening the threatening of face, it is also seen that the speaker does not use a head act request strategy; instead, the speaker employs internal modification devices by first rephrasing her question into an indirect speech and adding 'saya diminta tolong [name] untuk menanyakan kepada Bapak' before the actual question of asking the lecturer's availability to hold a meeting on the suggested day. Another example of the use of negative politeness strategies in talking with a hearer with a higher power and distance relationship is below:

\section{Datum 8 \\ DS: Maaf sebelumnya, Pak, berhubung minggu ini adalah minggu terakhir kuliah sebelum UAS, dan kami harus menyerahkan soal ujian dalam minggu ini, apakah memungkinkan jika deadline penyerahan abstrak hasil terjemahan dilonggarkan?}

The conversation above is taken from a text message between a lecturer in one faculty and a dean of another faculty in the same university. The context of the message is the speaker's proposing about the possibility to postpone the deadline of the submission of a translation project between the two faculties. Similar to Datum 1, the text begins with a negative politeness strategy of apologizing and followed by the address term ' $P a k$ ' to show deference. The speaker proceeds to give a reason before asking a question, which is also posed as a negative strategy in which the writer tries to minimize the imposition they make to the hearer by saying 'apakah memungkinkan'-asking whether it is possible to do something. This clearly shows that the speaker hopes not to impose the hearer by the request. These sub-strategies are repeated in most of the data in which the speaker's social power and distance are lower than that of the hearer's.
Different strategies are seen to be used by speakers of lower position but have close social distance with the hearers. The findings suggest that lower-ranking speakers who are close with the hearers tend to mix bald onrecord, positive politeness and negative politeness strategies in posing their request instead of only relying heavily on negative politeness strategies. The presence of modification devices is still seen, as seen in the following text between a worker and her superior at the office:

\section{Datum 20 \\ JEA: Eh ko, can I ask u a big favor? Gw the bingung nih \#curcol kan ini teh yang tema komsel bakal mulai jalan dari September- Desember, juli agustus teh belum. Kalo gw minta tolong koko untuk buat gmn? Sy oge buat gt. Koko kan selama ini buat, tp masuknya selasa. Nah kalo masuknya awalan gmn HAHAHAHA. Kalo ga bisa gpp sih. I understand soal ur work komitmen dll.}

In Datum 20, the context of the conversation is the speaker needs the hearer's help to work on the themes of their church cell group meetings. Here, we see that the speaker starts with a hedge 'eh' instead of a formal greeting. It shows that the speaker and the hearer are close. Another proof of this is the slang word ' $g w$ ' instead of the formal 'saya' to refer to the speaker. However, the speaker also acknowledges that she is in a more powerless position than the hearer by using the Mandarin term for big brother ' $k o$ ' in her text. In her first sentence, the speaker uses bald on-record strategy, request, by mentioning at the beginning that she wants to ask for a favor. However, in the next sentence the speaker switches strategy by giving background information and reason of her imposition, a strategy which falls to the category of positive politeness. This is followed by a negative strategy using hedging in question by adding the informal spelling of the word 'if' in Bahasa Indonesia, 'kalo', and 'gmn', or 'how'.

The rest of the text is another mixture of positive and negative politeness strategies; 'saya oge buat gt' serves as a positive strategy 
as the speakers suggests that she is also involved in the activity of creating the themes so as not to impose the hearer's face too much. Meanwhile 'nah kalau masuknya awalan gmn,' 'kalo ga bisa gpp sih' and 'I understand soal ur work komitmen dll' are a form of negative strategies used to minimize imposition on the hearer. In the first phrase, the speaker uses ' $n a h^{\prime}$ ', which has no equivalent of meaning in Indonesian, as a hedge for her request not to be taken as an order. It is strengthened by the second and third phrases, saying that it is alright if the hearer cannot comply with the request and that the speaker understands that the hearer has other work and commitments to fulfill. The mixture of strategies is also reflected in the uses of modification devices-the speaker uses both internal modification devices by hedging and external ones, by providing background to the request.

\section{Request Strategies Used by Equal Speaker and Hearer}

When the speaker considers that his/her power is equal to that of the hearer's, the speaker chooses a different strategy in posing requests. This may be due to the fact that there is less risk of threatening the face of the hearer. The findings suggest that the difference in social distance does not significantly change the way peers are communicating with one another, and therefore, the strategies that they use in requesting a favor, things and/or information are quite similar when analyzed through politeness and requesting strategies. Datum 26 below is an example of speaker with equal power position but is not close with the hearer, while Datum 32 is one whose speaker has equal power to and close with the hearer.

\section{Datum 26}

SF: Bu [name] masih inget UAS Filsafat? Aku asa masih kosong bgt. Dan di kelas pun cuma ngobrol2 geje gitu.

\section{Datum 32 \\ MG: Ci kmrn lu dpt kado apa? Gw butuh buat tuker kado lg}

The two data show that a question and a statement may serve as directives, specifically in this case, as requests. Datum 26, in which the speaker is the hearer's junior at university, uses a combination of off-record, negative politeness and positive politeness strategies. The speaker indirectly requests an explanation on the hearer's experience in Philosophy class in the form of a yes/no question-thus the data falls to the category of negative politeness strategy. The phrase 'masih inget' to ask whether the hearer still remembers about something suggests that the speaker is trying to be pessimistic about the matter, but at the same time it can be seen as a positive politeness strategy namely presupposing common ground that the hearer has also once experienced/taken the exam of said subject. The rest of the text gives explanation as to why the speaker needs the information, using an off-record strategy of being ironic.

Datum 32 uses a different strategy in terms of politeness strategies, since the speaker is a younger cousin of the hearer. In the data, the speaker opens her request by questioning the hearer about the present she got the other day before indirectly requesting that said present should be given to the speaker. In this case, the first sentence of the text shows the use of rhetorical question (an off-record strategy) because the speaker does not really intend to know what present the hearer got; she only asks to open the conversation so that she may, off-recordly, give hint that she needs the present for her own gift exchanging party. Again, as are found in the texts between lower-ranking and higher-ranking people, the request strategy in the two data is peripheral modification devices, especially external modification devices.

\section{Request Strategies Used by Higher- Ranking Speaker to Lower-Ranking Hearer}

The tendency of speaking less formally and without redress is higher when a speaker puts him/herself in a position of more power than the hearer, which can be seen in the findings of this research. Most of the data show people of higher power tend to use bald on-record strategies when speaking to lowerranking hearers (both close and not in social 
distance) as they recognize that their request will not threaten the face of the hearers, as can be seen in the following two data:

\section{Datum 40}

LT: Tolong belikan kado buat cucunya [name] titipkan ke tokonya

\section{Datum 49}

JA: [name] tolong belikan papa tempat obat yg seperti punya [name] buat pagi siang sore. Mama cari di Ausi ga ada.

Datum 40 is a text message between an employer and her assistant in which the speaker wants her assistant to buy a birthday present for the grandchild of the speaker's acquaintance. We can see that the only mitigating device in the text is the word 'tolong', translated 'please' in English, while the rest uses bald on-record strategy of requesting in imperative forms, 'belikan' and 'titipkan.' The lack of modification devices shows that the speaker puts herself in a position of power and she believes that her request does not threaten the face of the assistant as it is the assistant's job to do what she asks for.

Datum 49 is a request posed by a mother-in-law to her son-in-law, which puts the speaker in the position of power having close social distance with the hearer. The slight difference from Data 40 is the fact that the speaker in Datum 49 adds a reason behind her requesting the hearer to do something to her. In politeness strategy, giving reason is in the category of positive politeness strategy; in request strategy, this is considered as using external modification device.

\section{Conclusion}

Due to the time constraints in which the analysis is done, the present study is limited only to examining the speech act of requests in two text messaging applications. It is suggested that future researchers collect data not only in the form of texts but also in the form of recording so that the prosodic nature of the requests may be taken into account as text messages may not reveal the context of situation of the requests. Moreover, this study focuses solely on how the speaker poses his/her requests when texting people with different power and distance relations from them without regarding the hearer's response as a variable. Future studies may want to take the responses as a variable, adding turn takings as well as the sequence of request into their analysis since it may give another insight to the context of situation in addition to see whether the hearer shows signs of his/her face being threatened.

Another limitation is regarding the diversity of the participants from whom the text messages are obtained. While the researcher tries to choose random samples from the population, they are restricted to people residing in the big cities of West Java with more or less similar cultural and educational background. The researcher suggests that future research takes a more widespread samples so as to provide a more accurate conclusion.

The present study aims to see whether power and distance play a role in determining the (in)directness of a request in Indonesian people's text messages. The results indicate that in communicating with people of higher position or power, a speaker has the tendency to use negative politeness strategies in order to avoid threatening the face and imposing their will on the hearer. They also tend to use modification devices rather than stating their requests as a head act. On the contrary, a speaker of higher social power does not use redress when posing their requests - they use a bald on-record strategy to achieve the purpose of the communication, sometimes adding modification devices such as 'tolong'or 'please' in Bahasa Indonesia-to lessen the effect of their commands.

What the researcher finds as interesting is that when a speaker considers him/herself equal to the hearer in social power, there is a tendency to mix the politeness strategies instead of employing one category in their request. These speakers also use quite a lot of modification devices as a way of saving the hearer's (and possibly their own) face when requesting for favors, things, or information. 
Based on the strategy use differences, the researcher concludes that people in Indonesia are aware of the differences in social power and distance relations when communicating with other people. It is also drawn that this awareness causes Indonesians to employ different politeness strategies to accomplish their goals in their daily communication with people of higher, equal and lower social power from them. The uses of peripheral modification devices in the majority of the data also suggests that Indonesians are inclined to opt out from saying their requests directly in order to maintain a good relation with other people in addition to lessen the threats to their faces.

\section{References}

Al-Marrani Yahya Mohammed Ali and Sazalie, Azimah Binti. "Polite Request Strategies as Produced by Yemeni EFL Learners". Language in India. Strength for Today and Bright Hope for Tomorrow. 2010: 165188. ISSN 1930- 2940.

Aribi, Imen. "A Socio-Pragmatic Study of the Use of Requests in English by Tunisian EFL learners". Journal of Second Language Teaching and Research. Vol.2, no. 1, pp. 87-120. n.d. Web. 20 Jan. 2018. < http://pops.uclan.ac.uk/index.php/jsltr /article/view/92/39>.

Austin, John Langshaw. How to Do Things with Words. Oxford: Oxford University Press, 1962.

Black, Elizabeth. Pragmatic Stylistics. Edinburgh: Edinburgh University Press, Ltd., 2006.

Beltran, Elina Vilar and Flor, Alicia Martinez. “Analysing English Native Speakers' Use of Request Modification Devices during a Role-Play Activity". n.d. Web. 30 Jan. 2018.

http://www.um.es/lacell/aesla/contenid o/pdf/1/vilar.pdf>.
Bogdan, Robert C. and Biklen, Sari Knopp. (1982). Qualitative Research of Education: An Introduction to Theory and Methods. Boston: Allyn \& Bacon, 1982.

El-Samir, Sausen F. "Politenes: A SocioPragmatic Study". 2016. Web. 10 Mar. 2018.

$<$ http://www.iasj.net/iasj?func=fulltext\& aId=81619>.

Grundy, Peter. Doing Pragmatics. London: Hodder Education, 2008.

Kitamura, Noriko. "Adapting Brown and Levinson's 'Politeness' Theory to the Analysis of Casual Conversation". Proceedings of ALS2k. The 2000 Conference of the Australian Linguistic Society. 2000. Web. 1 Dec. 2017. <http://www.als.asn.au/proceedings/als 2000.html>.

Leech, Geoffrey. Principles of Pragmatics. London: Longman, 1983.

The Pragmatics of Politeness. Oxford: Oxford University Press, 2014.

Reiter, Rosina M. Linguistic Politeness in Britain and Uruguay: Contrastive Study of Requests and Apologies. Amsterdam/ Philadelphia:John Benjamins Publishing Company, 2000.

Sattar, Hiba Q. A. and Farnia, Maryam. "A Cross-Cultural Study of Request Speech Act: Iraqi and Malay Students". Applied research on English language. 2014. Vol. 3, no. 2, pp. 35-54.

Searle, John. Speech Acts: An Essay in the Philosophy of Language. Cambridge: Cambridge University Press, 1969.

Shariati, Mohammad and Chamani, Fariba. "Apology Strategies in Persian". Journal of Pragmatics. 2010. Vol. 42, no. 6, pp. 16891699.

Sifianou, Maria. Politeness Phenomena in England and Greece: A Crosscultural Perspective. Oxford: Oxford University Press, 1999. 
Watts, Richard J. Politeness. Cambridge: Cambridge University Press, 2003.

Yang, Lihong. The Speech Act of Request: A Comparative Study of Chinese and American Graduate Students at an American University. Thesis. Bowling Green State University, 2009.

Yule, George. Pragmatics. Oxford: Oxford University Press, 1996. 